Ann. Biol. anim. Bioch. Biophys., I976, 16 (3), 479-490.

\title{
CHARACTERIZATION AND PROPERTIES OF A HIGH AFFINITY OESTRADIOL RECEPTOR IN NEONATAL RAT BRAIN
}

\author{
D. F. SALAMAN, P. J. THOMAS* and B. R. WESTley \\ Department of Anatomy, \\ Medical School, University of Bristol, \\ Bristol, BS\& 1TD, U.K. \\ * Department of Pharmacology, \\ Chelsea College, \\ Manresa Road, London SW3, U.K.
}

\section{SUMMARY}

The high affinity oestrogen " receptor " $\left(\mathrm{K}_{d}\right.$ oestradiol ro $\left.^{-10} \mathrm{M}\right)$ from the neonatal rat brain shows the same hydrodynamic properties as other oestrogen " receptors" when analysed on sucrose density gradients before and after purification using ammonium sulphate precipitation. After this purification procedure, which also separates the small amount of " receptor " from the larger amount of lower affinity oestrogen binding protein $\left(K_{d}\right.$ oestradiol $\left.10^{-8} M\right)$, the apparent affinities of the putative neonatal oestrogen " receptor " for oestrone and oestradiol are increased towards the affinities of the adult hypothalamic oestrogen " receptor w for these steroids. When [ $\left.{ }^{3} \mathrm{H}\right]-$ oestradiol was injected intracerebrally, diethylstilboestrol-suppressible radioactivity was measured in the purified nuclear fraction of the neonatal brain and was maximal half to one hour after injection. It was localised mainly in the hypothalamic region and a sex difference in nuclear uptake was found. When this radioactivity was extracted, it sedimented at $4.5 \mathrm{~S}$ when analysed on gradients containing $0.4 \mathrm{M} \mathrm{KCl}$. This suggested that the nuclear material was derived from the cytosol high affinity protein and further experimentation showed a temporal correlation between the appearance of diethylstilboestrol-suppressed radioactivity in the nuclei and the disappearance of high affinity binding sites in the cytosol.

\section{INTRODUCTION}

It is well established that the neonatal rat brain may be affected by exposure to certain steroid hormones, and that this exposure results in a permanent alteration of gonadotrophin secretion and behavioural patterns in adult life (HARRIs, I964). The mechanism by which this process occurs has, however, remained obscure, 
although several theories have been put forward (Sheridan et al., I973 ; Salaman, I974). The most attractive is that oestrogens, derived by aromatization from testicular androgens, are the active group of steroids in the differentiating process (REDDY et al., I974) and that they act in a manner characteristic of steroid hormones, illustrated by the action of oestrogens on the uterus or progesterone on the avian oviduct (O'MALLEY and MEANS, 1974). This mechanism involves the binding of the effector hormone to receptors which may be found in the cytosol fraction prepared from target organs, and the subsequent movement of the steroid-receptor complex into the nucleus of the cell where transcriptional alterations ultimately result in the observed physiological changes of the target organ (JENSEN and DE SOMBRE, I972).

The major objection to this mechanism, as applied to the sexual differentiation of the brain, has been that no oestrogen receptors had been demonstrated in the neonatal brain. Recently, however, high affinity oestrogen binding $\left(\mathrm{K}_{d}\right.$ oestradiol $\sim 10^{-10} \mathrm{M}$ ) has been demonstrated in the brain of the neonatal rat (BARLEY et al., 1974) using a new highly sensitive technique (GINSBURG et al., I974). In this study we have investigated the properties of this high affinity binding protein further and compared them with the oestrogen " receptor" of the adult brain. We have also investigated the nuclear accumulation of $\left[{ }^{3} \mathrm{H}\right]$-oestradiol administered in vivo to establish whether the steroid- " receptor" complex could move to the nucleus in a manner similar to other steroid-receptor complexes, and ultimately modulate transcriptional events leading to the sexual differentiation of the brain.

\section{MATERIALS AND METHODS}

\section{Animals}

Male and female 4-day old Wistar rats (day of birth $=0$ ) from our own inbred strain were used throughout this study.

\section{Chemicals}

$\left[2,4,6,7,(n)-{ }^{3} \mathrm{H}\right] \mathrm{I}, 3,5$, (ro) oestratrien-3, I $7 \beta$-diol $\left(\left[{ }^{3} \mathrm{H}\right]\right.$-oestradiol) (specific activity, roo $\mathrm{Ci} / \mathrm{mmol}$ ), was obtained from The Radiochemical Centre, Amersham, Bucks., U.K. $\left[{ }^{3} \mathrm{H}\right]$-oestradiol was stored in benzene:ethanol, 95:5. The solvent was removed under a stream of nitrogen and the steroid then taken up in buffer. Sephadex LH-2o was obtained from Pharmacia (U.K.) Limited, London, U.K. Unlabelled I, 3, 5 (ro)oestratrien-3-ol, r 7one (œstrone), oestradiol and diethylstilboestrol (DES) were obtained from Sigma (London) Chemical Co. Ltd., Kingston-Upon-Thames Surrey, U.K. Stock solutions ( I $^{-4} \mathrm{M}$ ) of the unlabelled steroids in ethanol were diluted directly to the required concentration in buffer. All other chemicals were of Analar grade and solutions were made up in glass distilled water.

\section{Preparation of cytosol}

Four day old rats of either sex were killed by decapitation and brain tissue dissected into ice cold buffer. If required, the brains were perfused from the heart with ice cold saline to remove blood and blood oestrogen binding proteins (Plapinger et al., I973). The brain was removed, taking all tissue anterior to the mammillary bodies ("cerebrum "). All subsequent operations were carried out at $0-4^{\circ} \mathrm{C}$. The tissue was weighed, then homogenized by hand using a glass teflon homogenizer in ro $\mathrm{mM}$ sodium phosphate buffer $\mathrm{pH} 7 \cdot 3$. containing $0.25 \mathrm{M}$ sucrose and Ioo $\mathrm{mM}$ mercaptoethanol (buffer A). For the experiments involving ammonium sulphate precipitation the cytosol was prepared in Io $\mathrm{mM}$ sodium phosphate buffer $\mathrm{pH} 7.3$ alone (buffer $\mathrm{B}$ ). Generally $0.5 \mathrm{~g}$ of tissue was homogenized in $\mathrm{I} \mathrm{ml}$ of buffer. The homogenate was spun for $\mathrm{I} \mathrm{h}$ at $2^{\circ} \mathrm{C}$ and 200 , 000 $g\left(r_{a v} 6.43 \mathrm{~cm}\right)$ in an MSE $10 \times 10 \mathrm{ml}$ titanium angle rotor. The supernatant (cytosol) 
was used in all experiments. The cytosol was incubated with the required steroids for $3^{\circ} \mathrm{min}$ at $3^{\circ} \mathrm{C}$ or $\mathrm{I} 6 \mathrm{~h}$ at $2^{\circ} \mathrm{C}$. For all the sucrose density gradient experiments a concentration of approximately ro- ${ }^{9} \mathrm{M}\left[{ }^{3} \mathrm{H}\right]$-oestradiol with or without a 200 fold excess of DES was used.

\section{LH-20 chromatography}

The method of GinsBurg et al. (I974) was followed throughout, except that the first $200 \mu 1$ of column eluate was discarded as it contained an insignificant amount of radioactivity. Also the labelled cytosol was in contact with the gel for $150 \mathrm{~min}$ as reported by BARLEY et al. (I974) to dissociate the lower affinity bound oestradiol. After elution from the LH2o columns, the column eluate was dialysed for $4 \mathrm{~h}$ against buffer $\mathrm{B}$ to remove sucrose and further reduce the concentration of free steroid. The amount of high affinity material that could be applied to a sucrose gradient from an $\mathrm{LH}_{2}$ o column eluate was very small, we therefore used conditions of high protein concentrations and saturating $\left[{ }^{3} \mathrm{H}\right]$-oestradiol concentrations (approximately $10^{-9} \mathrm{M}$ ) to maximise the amount of high affinity complex applied to the gradient, while still removing most of the low affinity bound radioactive steroid. Perfusion of the brains as described, and dialysis of the column eluates also helped to minimise the lower affinity binding seen on the sucrose gradients.

\section{Ammonium sulphate fractionation}

The method employed was based on that of PuCA et al. (I97I) for the partial purification of the uterine oestradiol receptor. Cytosol was prepared from unperfused brain tissue in buffer $B$ and incubated with $\left[{ }^{3} \mathrm{H}\right.$ [-oestradiol as described. Saturated ammonium sulphate, adjusted to $\mathrm{pH} 7.3$ with aqueous. $\mathrm{NH}_{3}$ solution was added dropwise to $25 \mathrm{p}$. Ioo saturation, left on ice for $2 \mathrm{~h}$, then the precipitate collected by centrifugation for $20 \mathrm{~min}$ at $2^{\circ} \mathrm{C}$ and $60,000 \mathrm{~g}\left(r_{a v} 6.43 \mathrm{~cm}\right)$ in an MSE Io $\times$ ro $\mathrm{ml}$ titanium angle rotor. The pellet was redissolved in $\mathrm{I} / \mathrm{I}$ oth the original volume of cytosol in buffer $B$ and then dialysed for $4 \mathrm{~h}$ against the same buffer before analysis on sucrose gradients. For experiments measuring the affinity of the ammonium sulphate precipitated material, the pellet was taken up in approximately $1 / 2$ the original volume of cytosol and then incubated with the required concentrations of steroids.

\section{Measurement of binding affinity}

The method of Ginsburg et al. (1974) using the LH2o technique was used throughout.

\section{Nuclear upiake of radioactivity}

Animals were injected intracerebrally using the method of BARNEA and LINDNER (I972) with $2.5 \mu \mathrm{Ci}$ of $\left[{ }^{3} \mathrm{H}\right]$-oestradiol in Io $\mu$ l saline with or without DES $\left(0.5 \times 10^{-4} \mathrm{M}\right)$. Radioactivity was measured in the initial homogenate and in purified nuclear fractions prepared by the method of Plapinger and McEwen (I973). For the time courses and the extraction of nuclei with $0.4 \mathrm{M}$ $\mathrm{KCl}$, nuclei were prepared from the whole " cerebrum ». For the distribution experiments the brain was divided into four parts, " ant cort " including all brain anterior to the optic chiasma, " cereb" including all brain posterior to the mammillary bodies, " sup cort " including the upper half of the remaining cerebral tissue and " hyp " the lower half.

\section{Extraction of nuclear radioactivity}

Nuclei from intracerebrally injected animals were extracted with $0.4 \mathrm{M} \mathrm{KCl}$ (pH 8 ) for one hour. The nuclei were sonicated at time o and $3^{\circ} \mathrm{min}$ for $5 \mathrm{sec}$. with a Dawe soniprobe with micro tip at 30 watts. The extracts were then centrifuged for $30 \mathrm{~min}$ at $2^{\circ} \mathrm{C}$ and roo, ooo $g\left(r_{a v} 6.43 \mathrm{~cm}\right)$ in an MSE Io $\times 10 \mathrm{ml}$ titantium angle rotor. The supernatant $(200 \mu \mathrm{l})$ was layered onto 7-30 $\mathrm{p}$. I00 sucrose density gradients containing $0.4 \mathrm{M} \mathrm{KCl}$ and centrifuged as described.

\section{Cytosol depletion of high affinity binding sites}

Animals were injected as described. Only the "hyp " regions from female animals were used in these experiments. One half of the "hyp " region from each animal was collected for the measurement of nuclear radioactivity as described. Cytosol was prepared as described from the other halves. The number of sites occupied in the cytosol was determined from the difference in radio- 
activity between column eluates of rats injected with and without DES after passage of the cyosol through sephadex $\mathrm{LH}_{2}$ o columns. The total number of available sites in the cytosol was measured using the sephadex LH2o method of GinsBurg et al. (1974).

\section{Measurement of radioactivity}

Samples to be counted were collected in polypropylene vials and extracted with ro $\mathrm{ml}$ of scintillation fluid (2,5-diphenyloxazole (PPO) $4 \mathrm{~g} / 1, \mathrm{I}, 4$-di-2-(5 phenyloxazoyl)-benzene (POPOP) o.I $\mathrm{g} / \mathrm{l}$ in toluene) overnight before counting with an efficiency of approximately 50 p. roo in a Beckmann model LSroo liquid scintillation counter.

Protein was estimated by the method of LowRY et al. (I95I) using crystalline bovine serum albumin as standard. DNA was measured by the method of BuRTON (1956).

\section{RESULTS}

Figure I shows a sucrose density gradient of cytosol, prepared from 4-day old female rat brains incubated with $\left[{ }^{3} \mathrm{H}\right]$-oestradiol for 30 min at $30^{\circ} \mathrm{C}$. Only a single large peak of radioactivity sedimenting at $4.5 \mathrm{~S}$ was seen and it was not reduced by

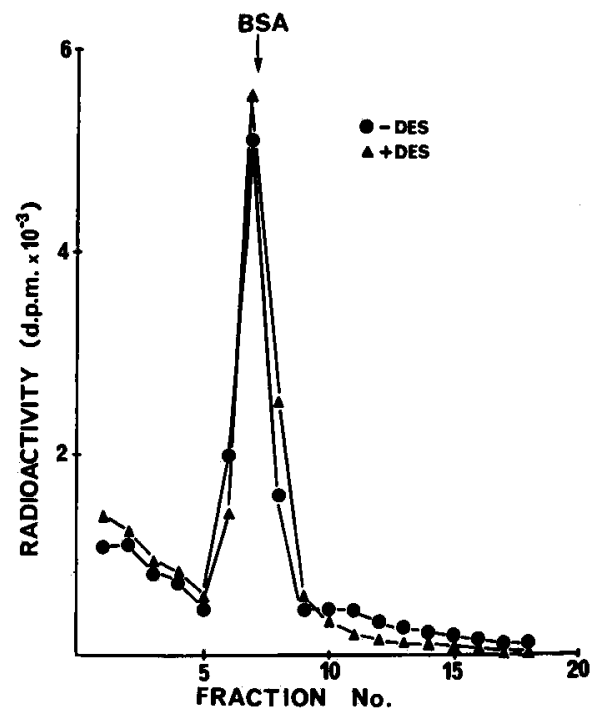

Fig. I. - Cytosol prepared from cerebrum of 4 day female rats incubated teith $\left[{ }^{3} \mathrm{H}\right]$-oestradiol alone (•) for 30 min at $30^{\circ} \mathrm{C}$, or in the presence of a 200 fold excess of DES (4), analysed on 7-30 p. 100 sucrose gradients containing buffer $B$. Centrifugation was from left to right for $16 \mathrm{~h}$ at $2^{\circ} \mathrm{C}$ and $300,000 g_{a v}$. Arrow indicates position of bovine serum albumin (4.6S) run on a parallel gradient.

a 200 fold excess of DES in the incubation. This material has been described previously (PIAPINGER et al., I973; WeSTI.EY and SALAMAN, I974) and is the low affinity $\left(\mathrm{K}_{d} \mathrm{IO}^{-8} \mathrm{M}\right)$ oestrogen binding protein $(\mathrm{EBP})$ of the blood and brain of the neonatal rat. If, however, the cytosol was first passed through a Sephadex LHzo column to remove the free and low affinity bound oestradiol, the large peak sedimenting at $4.5 \mathrm{~S}$ was removed to reveal a very much smaller peak sedimenting at $7-8 \mathrm{~S}$. This material was suppressed by DES and sedimented at $4.5 \mathrm{~S}$ on gradients containing 
$0.4 \mathrm{M} \mathrm{KCl}$ (fig. $2 a$ ). A similar pattern of peaks was seen if the incubation was carried out at $0-4^{\circ} \mathrm{C}$ for $\mathrm{I} 6 \mathrm{~h}$ (fig. $2 \mathrm{~b}$ ) and also when the tissue was divided into cortical and hypothalamic/amygdaloid regions. We believe this material to be the oestrogen " receptor" described by BARLEY et al. (I974).
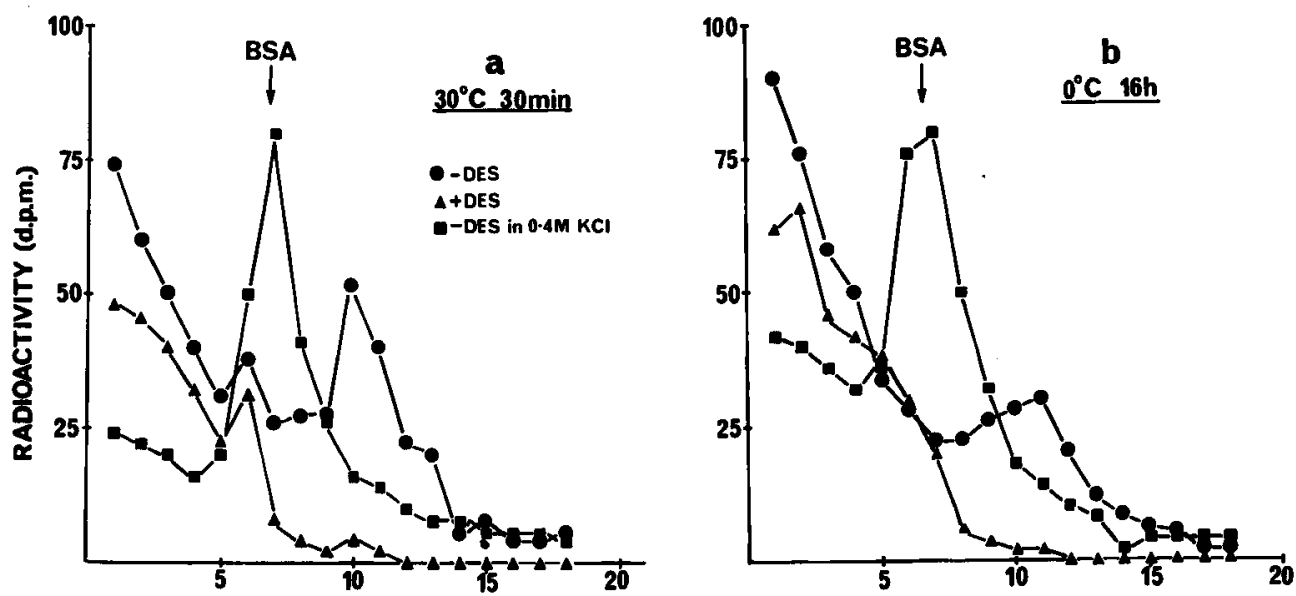

FIG. 2. - Sephadex LH2O column eluate of cerebral cytosol from 4 day female rats analysed on sucrose gradients

(a) incubated for $30 \mathrm{~min}$ at $30^{\circ} \mathrm{C}$

(b) incubated for $16 \mathrm{~h}$ at $0^{\circ} \mathrm{C}$. Conditions and symbols as in figure I except (a) gradients containing $0.4 \mathrm{M} \mathrm{KCl}$ in buffer $\mathrm{B}$.

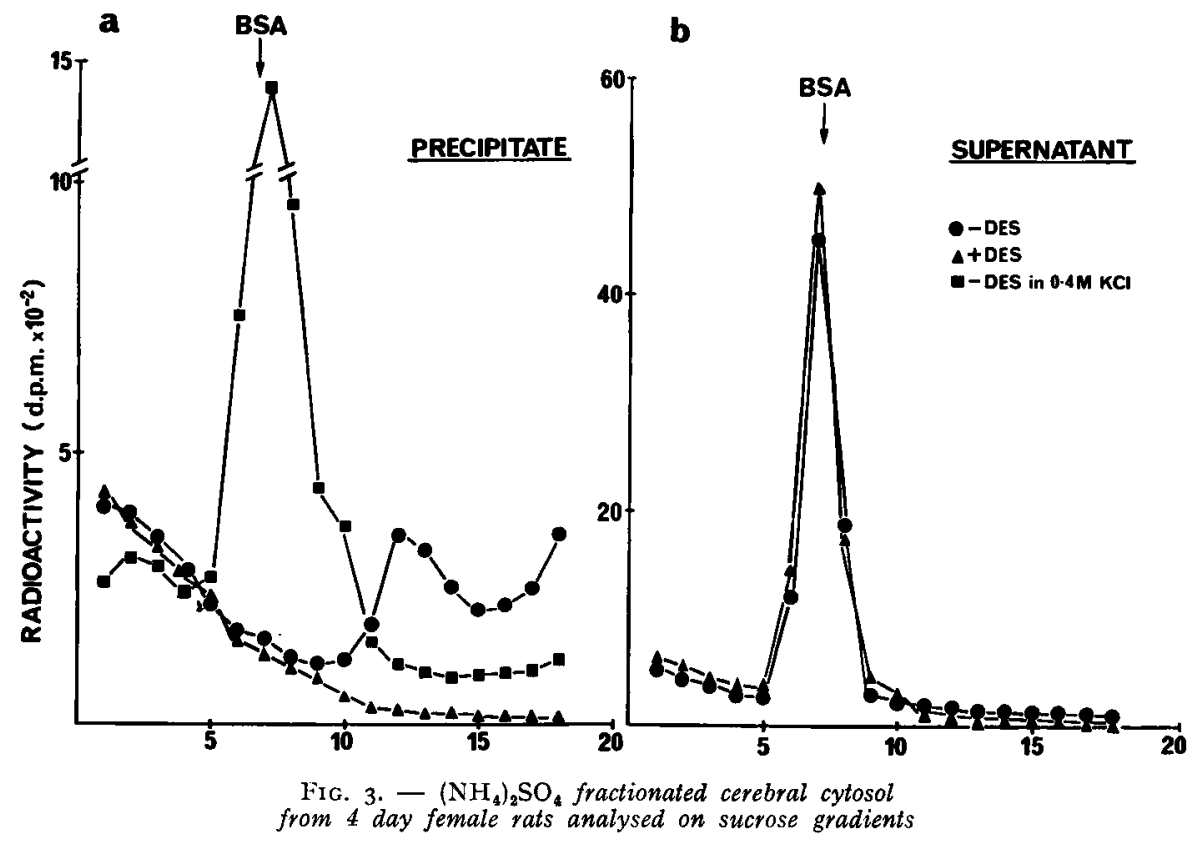

(a) dialysed precipitate from 25 p. Ioo saturated $\left(\mathrm{NH}_{4}\right)_{2} \mathrm{SO}_{4}$ treatment

(b) dialysed supernatant (details in Methods); conditions and symbols as in figures $\mathrm{I}$ and 2. 
The concentration of the $8 \mathrm{~S}$ material in the neonatal brain was very low, and this made detailed analysis of this material extremely difficult. We have therefore purified this material using ammonium sulphate precipitation.

Figure $3 a$ shows sucrose density gradients of the dialysed $\left(\mathrm{NH}_{4}\right)_{2} \mathrm{SO}_{4}$ precipitate prepared from cytosol incubated with $\left[{ }^{3} \mathrm{H}\right]$-oestradiol for 30 min at $30^{\circ} \mathrm{C}$. A DESsuppressed 7-8S peak and heavier aggregated material may be seen both of which sedimented at $4.5 \mathrm{~S}$ on gradients containing $0.4 \mathrm{M} \mathrm{KCl}$. Aggregation of purified receptor on low ionic strength gradients has been reported for the oestrogen receptor of the uterus (PUCA et al., I97I). There was no evidence of DES non-suppressible low affinity $\mathrm{E}, \mathrm{BP}$ on the low salt gradients. If, however, the supernatant from the $\left(\mathrm{NH}_{4}\right)_{2}$ $\mathrm{SO}_{4}$ precipitation was analysed on similar gradients the large peak of $4.5 \mathrm{~S}$ DES nonsuppressible material could be seen (fig. $3 b$ ) showing that we have effected at least a partial separation of high and low affinity oestrogen binding proteins.

TABLE I

Effect of $\left(\mathrm{NH}_{4}\right)_{2} \mathrm{SO}_{4}$ purification of the neonatal "receptor" on its affinity for oestradiol and oestrone

\begin{tabular}{|c|c|c|}
\hline & $\begin{array}{l}\mathrm{K}_{d} \text { oestrone } \\
\left(\mathrm{M} \times 10^{9}\right) \\
\text { mean } \pm \mathrm{SL}\end{array}$ & $\begin{array}{l}\mathrm{K}_{d} \text { oestradiol } \\
\left(\mathrm{M} \times 10^{10}\right) \\
\text { mean } \pm \mathrm{SE}\end{array}$ \\
\hline Neonate $\left({ }^{1}\right)$ crude & $23.59+8.33$ & $6.13+1.12$ \\
\hline Neonate purified & $5.71 \pm 0.97$ & $2.58+0.33$ \\
\hline Adult $\left({ }^{1}\right)$ & $1.72 \div 0.1$ & $1.48+0.27$ \\
\hline
\end{tabular}

(1) Data from Barle1: et al. (1974).

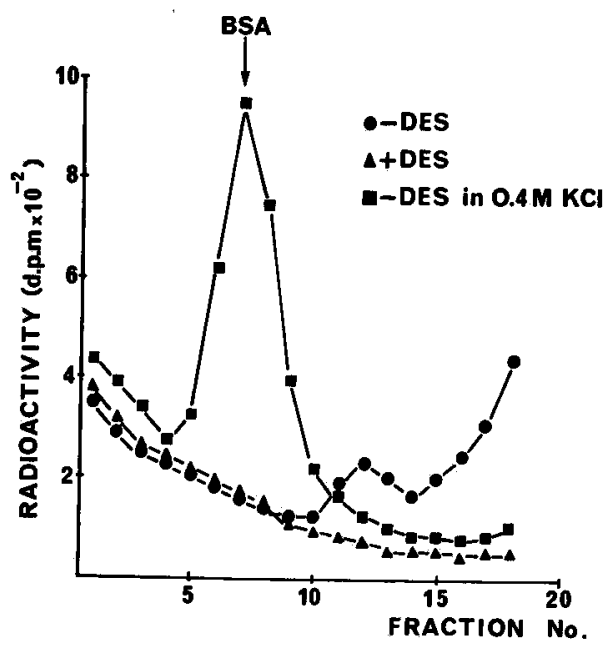

FIG. 4. - $\left(\mathrm{NH}_{4}\right)_{2} \mathrm{SO}_{4}$ fractionated hypothalamic cytosol from adult female rats analysed on sucrose gradients

Conditions and symbols as in figures $I$ and 2 
a

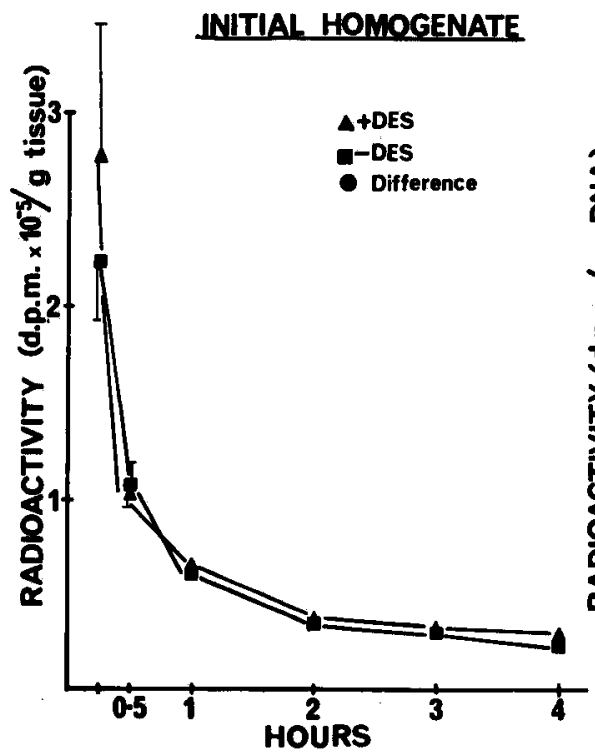

NUCLEAR PELLET DIFFERENCE

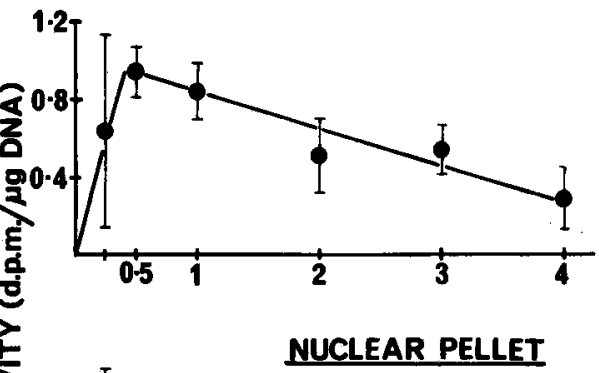

b
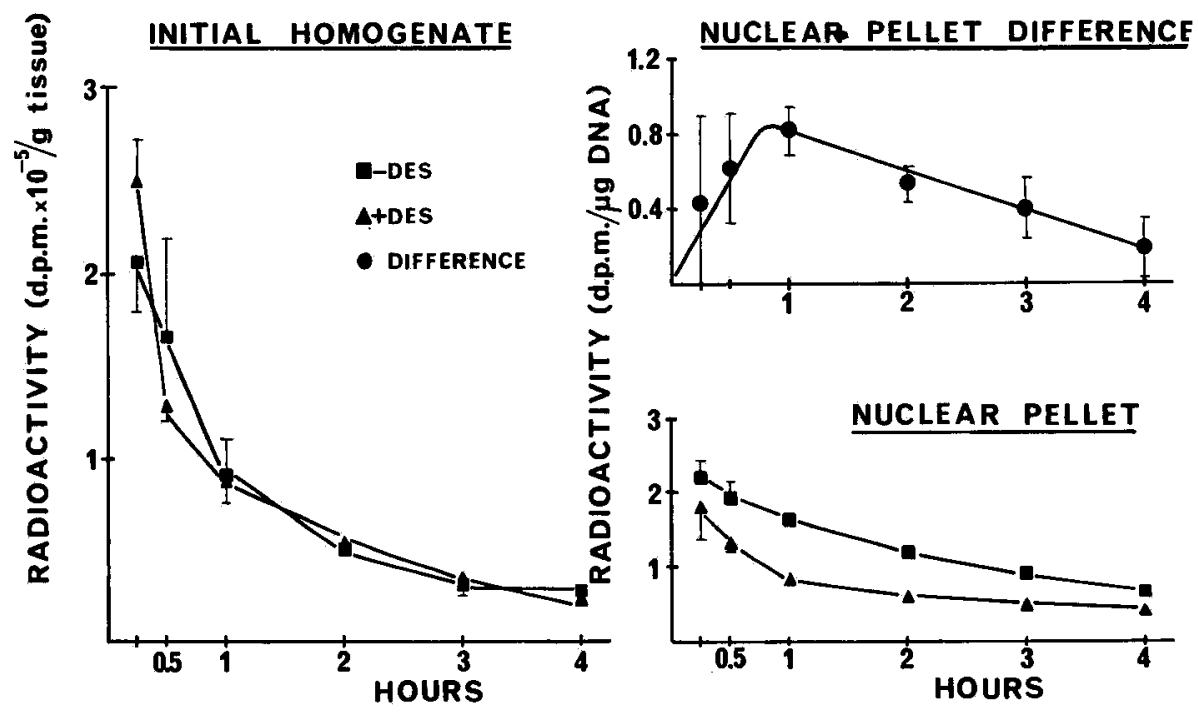

FIG. 5. - Time course of whole tissue and nuclear accumulation of $\left[{ }^{3} \mathrm{H}\right]$-oestradiol in cerebrum of (a) female and (b) male neonatal rats. Animals were injected intracerebrally with $2.5 \mu \mathrm{Ci}\left[{ }^{3} \mathrm{H}\right]$-oestradiol $(\square)$ or $2.5 \mu \mathrm{Ci}\left[{ }^{3} \mathrm{H}\right]$-oestradiol together with a 20 fold excess of DES (A). Radioactivity was measured in the initial homogenate of cerebral tissue and in the nuclear pellet prepared as in Methods. ( $\bullet$ ) represents the DES-suppressible radioactivity in the nuclear fraction. Bars indicate SEM limits where greater than the size of the symbol. 
When the binding affinity of the $\left(\mathrm{NH}_{4}\right)_{2} \mathrm{SO}_{4}$ precipitated material was measured using the Sephadex $\mathrm{LH} 20$ technique we found that the affinity of the purified neonatal material for oestradiol and oestrone was greater than that of the crude cytosol and had increased towards the values of the adult hypothalamic oestrogen " receptor " for these steroids (table I). It therefore seems that the adult and neonatal materials have similar affinities and that the apparent differences between them in affinity for oestradiol and oestrone are due to the presence of the lower affinity EBP in the neonatal cytosol as originally suggested by BARLEY et al. (I974).

We have also purified the oestrogen " receptor " from the adult female hypothalamus using $\left(\mathrm{NH}_{4}\right)_{2} \mathrm{SO}_{4}$ precipitation and it shows similar behaviour and properties to the neonatal material when analysed on sucrose density gradients (fig. 4).

Figure $5 a$ shows the levels of radioactivity in the initial homogenate and purified nuclear fraction of female neonatal cerebrum at various times after an intracerebral injection of $\left[{ }^{3} \mathrm{H}\right]$-oestradiol with and without a 20 fold excess of DES. It shows that the levels of radioactivity in the initial homogenate declined from the earliest time of measurement whereas the DES suppressed nuclear radioactivity, which we take to be the specifically bound $\left[{ }^{3} \mathrm{H}\right]$-oestradiol, was maximal half to one hour after injection and then declined in a linear fashion thereafter. A similar picture was seen for the males (fig. 5 b).

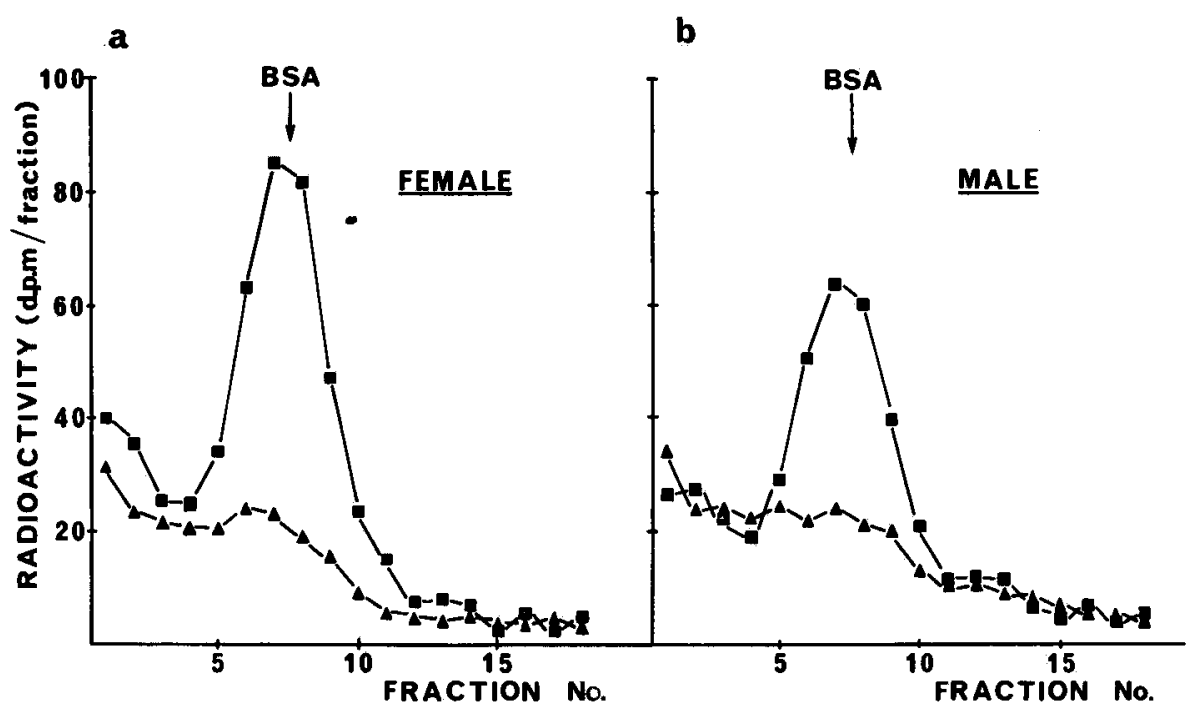

FIG. 6. - 0.4 M KCl extract of nuclei prepared from cerebrum of (a) female and (b) male neonatal rats injected with $\left[{ }^{3} \mathrm{H}\right]$-oestradiol $(\square)$ or $\left[{ }^{3} \mathrm{H}\right]$-oestradiol together with a 20 fold excess of DES $(\Delta)$.

Conditions of centrifugation as in figure I

Figure 6 shows the $0.4 \mathrm{M} \mathrm{KCl}$ nuclear extract analysed on gradients containing $0.4 \mathrm{M} \mathrm{KCl}, \mathrm{A} \cdot 4.5 \mathrm{~S}$ peak was seen which was suppressed by DES in extracts of nuclei from both male and female brain and this shows that the specifically bound radioactivity was associated with a macromolecule possessing similar properties to the cytosol " receptor " on gradients containing $0.4 \mathrm{M} \mathrm{KCl}$. 
Figure 7 shows the regional distribution of radioactivity in four regions of the male and female neonatal brain one hour after an intracerebral injection of $\left[{ }^{3} \mathrm{H}\right]$ oestradiol. It shows that while the total radioactivity at this time is distributed

a

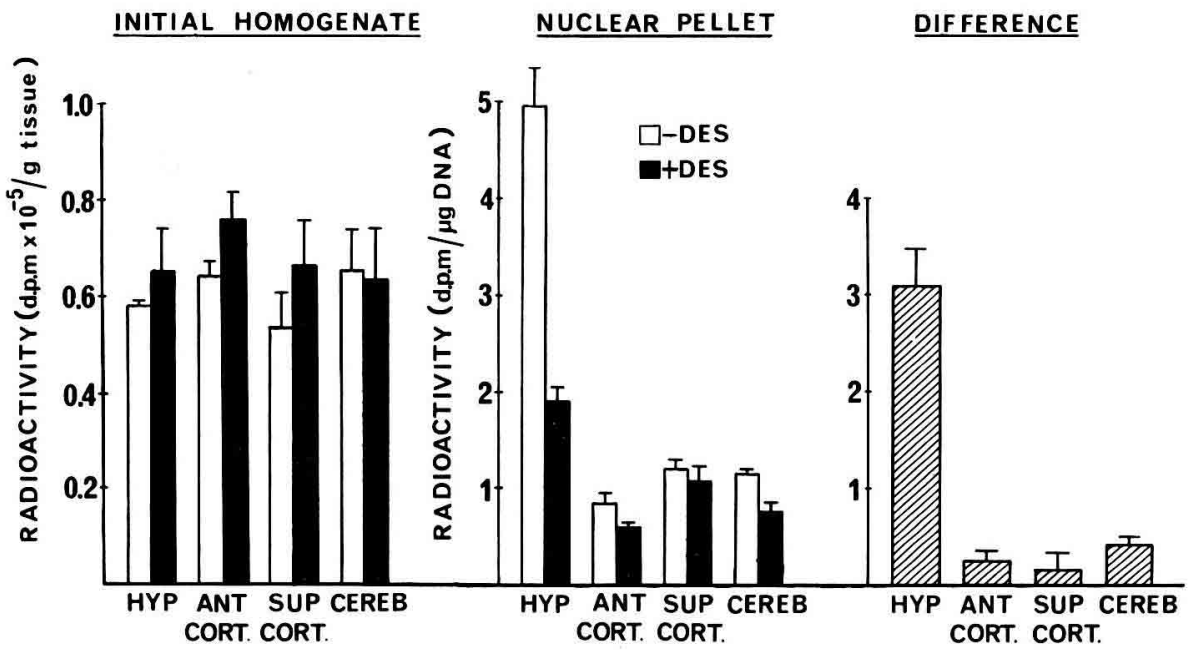

b
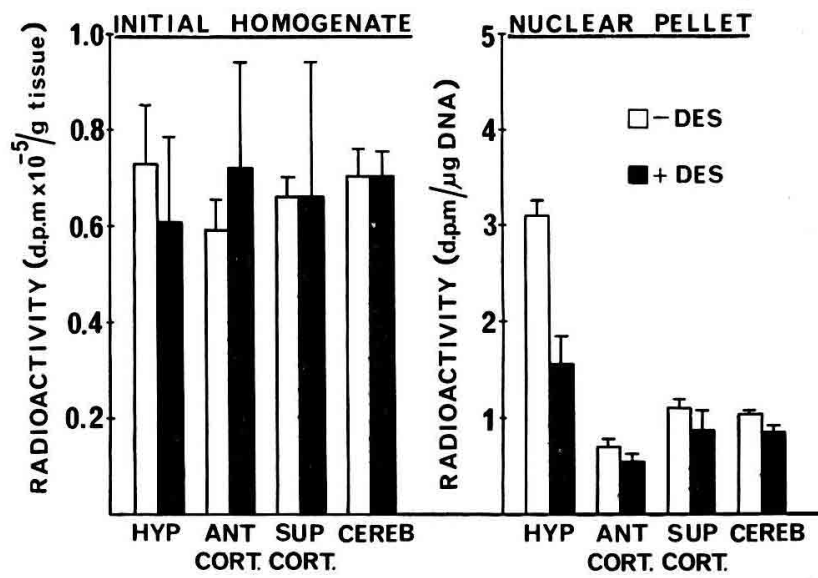

DIFFERENCE

FIG. 7. - Distribution of whole tissue and nuclear accumulation of $\left[{ }^{3} \mathrm{H}\right]$-oestradiol in various brain regions of (a) female and (b) male neonatal rats. Radioactivity was measured $\mathrm{I} h$ after intracerebral injection of $\left[{ }^{3} \mathrm{H}\right]$-oestradiol $(\square)$ or $\left[{ }^{3} \mathrm{H}\right]$-oestradiol together with a 20 fold excess of DES (ם) in the initial homogenate and the nuclear fraction of 4 brain regions dissected as described in Methods. (/II/) represents the DES-suppressible radioactivity in the nuclear fraction. Bars indicate SEM limits.

equally throughout the brain of both the male and female neonate, the majority of the DES suppressed radioactivity in the purified nuclear fraction is associated with the hypothalamic/amygdaloid region, and that there is more DES suppressed radio- 
activity in the hypothalamic region of the female than the same region of the male. These differences cannot be accounted for by transient differences in the distribution of the radioactive steroid between the different areas since measurement of total radioactivity at 5 , Io and $\mathrm{I}_{5} \mathrm{~min}$ after the intracerebral injection show that levels in the hypothalamic region do not exceed those in the other regions and that levels were declining from 5 min after injection.

Finally we have investigated the appearance of DES-suppressed nuclear radioactivity and the disappearance of high affinity binding sites in the cytosol fraction after a cerebral injection of $\left[{ }^{3} \mathrm{H}\right]$-oestradiol. Table 2 shows that there was a temporal relationship between these two but the depletion of high affinity cytosol sites was greater than the number of DES suppressed sites in the nucleus at any one time. We suggest that either DES-suppressed radioactivity was being lost from the nuclei during purification or that the cytosol " receptor " was moving to other cellular compartments apart from the nucleus.

TABLE 2

Cytosol depletion and nuclear binding of oestradiol "receptor" in female neonatal rat hypothalamus

\begin{tabular}{c|c|c|c}
\hline \hline $\begin{array}{c}\text { Time after } \\
\text { injection } \\
(\mathrm{m})\end{array}$ & $\begin{array}{c}\text { Total no. sites } \\
\text { in cytosol/g tissue } \\
\left(\times 10^{-10}\right)\end{array}$ & $\begin{array}{c}\text { No. sites bound } \\
\text { in cytosol/g tissue } \\
\left(\times 10^{-10}\right)\end{array}$ & $\begin{array}{c}\text { No. sites bound } \\
\text { in nuclei/g tissue } \\
\left(\times 10^{-10}\right)\end{array}$ \\
\hline 0 & 12.4 & $-\overline{0.5}$ & $-\overline{0.5}$ \\
15 & 10.2 & 0.91 & 1.2 \\
60 & 6.0 & & \\
\hline \hline
\end{tabular}

\section{DISCUSSION}

The results presented in this paper show firstly that the high affinity oestrogen binding protein of the neonatal brain and the oestrogen "receptor " of the adult female hypothalamus share similar hydrodynamic properties both before and after purification by $\left(\mathrm{NH}_{4}\right)_{2} \mathrm{SO}_{4}$. Secondly that the affinities of this material for oestrone and oestradiol are increased towards the values of the adult oestrogen " receptor " when the neonatal lower affinity $\mathrm{E}, \mathrm{BP}$ is removed. 'Thirdly that radioactivity is accumulated in the nuclear fraction of the neonatal brain in a DES-suppressible manner after an intracerebral injection of $\left[{ }^{3} \mathrm{H}\right]$-oestradiol. This accumulation is maximal half to one hour after injection, is localised mainly in the hypothalamic/amygdaloid region and is greater in the female than in the male. This radioactivity may be extracted by $0.4 \mathrm{M} \mathrm{KCl}$.

We suggest that the adult and neonatal " receptors" could be the same protein as they have so many properties in common. The only difference that has been measured is in their affinities for oestradiol and oestrone and we suggest that this could be artifactual and due to the presence of large amounts of low affinity EBP in 
the cytosol prepared from neonatal animals (BARLEY et al., I974). After $\left(\mathrm{NH}_{4}\right)_{2} \mathrm{SO}_{4}$ purification these differences are greatly reduced but still not abolished. This may mean that the adult and neonatal "receptors" are the same and that the differences are due to residual traces of EBP after purification or it may reflect a real difference between the neonatal and adult " receptors ". Further purification of the "receptors" should resolve this question. There is however a considerable difference in the distribution of the neonatal and adult " receptors". The former is distributed throughout the cerebrum of the neonate while the latter is confined largely to the hypothalamus and amygdala (GINSBURG et al., I974). However we have shown in this study that the in vivo nuclear uptake of oestradiol in the neonatal brain is predominantly localised in the hypothalamic region and this cannot be accounted for by differences in distribution of radioactive steroid to the different regions of the brain. This localisation is in agreement with an autoradiographic study of SHERIDAN et al. (I974) and a study of nuclear oestradiol binding after a subcutaneous injection of $\left[{ }^{3} \mathrm{H}\right]$ testosterone (LIEBERBURG and McEWEN, I975).

We have also found a sex difference in the specific nuclear uptake of oestradiol in the neonatal animal. This difference may be a result of transcriptional changes induced by very early exposure of the brain to testicular androgens or may be due to the partial occupation of nuclear " acceptor " sites in the male brain.

In conclusion we have demonstrated that the neonatal rat brain possesses the mechanism for responding to oestrogenic hormones and it now remains to be established whether this system is functioning in the sexual differentiation of the brain or in some other process.

Sexual Maturation, 3rd Workshop, August 31, September 3, 1975.

\title{
RÉSUMÉ
}

\author{
CARACTÉRISATION ETT PROPRIÉTÉS \\ D'UN RÉCEAPTEUR A L'ESTRADIOL A FORTE AFFINITÉ \\ DANS LE CERVEAU DU RAT DANS LA PÉRIODE NÉONATALE
}

I.e " récepteur " à l'estrogène à forte affinité $\left(K_{d}\right.$ estradiol $\left.10^{-10} \mathrm{M}\right)$ du cerveau de Rat dans la période néonatale a les mêmes propriétés hydrodynamiques que les autres " récepteurs " à l'estrogène, quand on l'analyse dans des gradients de densité au sucrose avant et après purification par précipitation au sulfate d'ammonium. Après cette purification qui permet de séparer de petites quantités de " récepteur " d'une quantité plus importante d'une protéine liant l'estrogène avec une affinité plus faible $\left(\mathrm{K}_{a}\right.$ estradiol $\left.I^{-8} \mathrm{M}\right)$ les affinités apparentes du " récepteur " néonatal présumé pour l'estrone et l'estradiol approchent celles du “ récepteur " à l'estrogène de l'hypothalamus adulte pour ces mêmes stéroïdes. Après injection intracérébrale d' $\left[{ }^{3} \mathrm{H}\right]$-estradiol, la radioactivité (qu'on peut faire disparaître par le diéthylstilbestrol) mesurée dans la fraction nucléaire purifiée, est à son maximum une demi-heure à une heure après l'injection. Elle est essentiellement localisée dans la région hypothalamique et on observe une différence entre les sexes dans la fixation nucléaire.

$\mathrm{Si}$ on extrait la radioactivité, elle sédimente à $4,5 \mathrm{~S}$ quand on l'analyse dans des gradients contenant $0,4 \mathrm{M} \mathrm{KCl}$. Ceci suggère que le matériel nucléaire provient d'une protéine cytosolique à forte affinité. L'expérimentation met en évidence une corrélation temporelle entre l'apparition de la radioactivité sensible au diéthylstilbestrol dans le noyau et la disparition des sites de fixation à forte affinité dans le cytosol. 


\section{REFERENCES}

Barley J., Ginsburg M., Greenstein B, D., Mclusky N. J., Thomas P. J., 1974 . A receptor mediating sexual differentiation? Nature, 252, 259-260.

Barnea A., Lindner H. R., I972. Short term inhibition of macro-molecular synthesis and androgeninduced sexual differentiation of the rat brain. Brain Research, 45, 479-487.

Burton K., I956. A study of the conditions and mechanism of the diphenylamine reaction for the colorimetric estimation of deoxyribonucleic acid. Biochem. J., 62, 315-323.

Ginsburg M., Greenstein B. D., Mclusky N. J., Morris I. D., Thomas P. J., I974. An improved method for the study of high-affinity steroid binding : oestradiol binding in brain and pituitary. Steroids, 23, 773-793.

HaRris G. W., 1964. Sex hormones, brain development and brain function. Endocrinology, 75, 627-648.

Jensen E. V., De Sombre E. R., I972. Mechanism of action of the female sex hormones. Ann. Rev. Bioch., 41, 203-230.

Lieberburg I., McEwen B. S., 1975. Estradiol-I7 $\beta$ : a metabolite of testosterone in cell nuclei from limbic areas of neonatal rat brains. Brain Research, 85, I65-r7o.

Lowry O. H., Rosebrough N. J., Farr A. L., Randald R. J., I951. Protein measurement with the Folin phenol reagent. J. Biol Chem., 193, 265-275.

O'Malley B. W., Means A. R., I974. Female steroid hormones and target cell nuclei. Science, 183, 6IO-620.

Plapinger L., McEwer B. S., 1973. Ontogeny of estradiol-binding sites in rat brain. I. Appearance of presumptive adult receptors in cytosol and nuclei. Endocrinology, 93, III9-x I28.

Plapinger L., McEwen B. S., Clemens L. E., I973. Ontogeny of estradiol-binding sites in rat brain II. Characteristics of a neonatal binding macro-molecule. Endocrinology, 93, II 29 -I 139 .

Puca G. A., Nola E., Sica V., Brescianar F., I97r. Studies on isolation and characterization of estrogen binding proteins of calf uterus. Adv. Biosci., $7,97-113$.

Reddy V. V. R., Naftolin F., Ryan K. J., 1974. Conversion of androstenedione to estrone by neural tissues from fetal and neonatal rats. Endocrinology, 94, II7-I2I.

SaLAman D. F., r974. The role of DNA, RNA and protein synthesis in sexual differentiation of the brain. In : Integrative Hypothalamic Activity. Progr. Brain Res., 41, 349-36r.

Sheridan P. J., Madhabananda, Sar., StumpF W. E., 1974. Autoradiographic localization of ${ }^{3} \mathrm{H}-$ estradiol or its metabolites in the central nervous system of the developing rat. Endocrinology, 94, I386-I390.

Sheridan P.J., Zarrow M. X., Denenberg V. H., I973. The role of gonadotrophins in the development of cyclicity in the rat. Endocrinology, $92,500-508$.

Westley B. R., Salaman D. F., I974. Evidence for a specific oestradiol-binding protein in neonatal rat brain. J. Endocr., 68, 54-55. 